\title{
Monitoring of the Influence of Landfills on the Atmospheric Air Using Bioindication Methods on the Example of the Zhytomyr Landfill, Ukraine
}

\author{
Myroslav Malovanyy $^{1 *}$, Mariia Korbut ${ }^{2}$, Irina Davydova ${ }^{2}$, Ivan Tymchuk ${ }^{1}$ \\ 1 Viacheslav Chornovil Institute of Sustainable Development, Lviv Polytechnic National University, \\ S. Bandera Str. 12, Lviv, 79013, Ukraine \\ 2 Zhytomyr Polytechnic State University, 103, Chudnivska str., Zhytomyr, 10005, Ukraine \\ * Corresponding author's e-mail: i.s.tymchuk@gmail.com
}

\begin{abstract}
The paper presents the results of research on the implementation of monitoring of the landfills influence on the atmospheric air using bioindication methods on the example of the Zhytomyr landfill (Ukraine)-one of the typical Ukrainian landfills, which is operated with minimal environmental protection measures. A comprehensive study of atmospheric air pollution in the landfill area was carried out using a human sensor system and an integral assessment using bioindication (lichens were chosen as bioindicators). The study revealed a reliable exponential dependence for modeling the relationship between the distance from the source of gas formation (solid waste landfill in the city of Zhytomyr) and the intensity of odor. The level of atmospheric air pollution was also determined based on the assessment of the projective coverage of the tree trunk with lichens. The research revealed an exponential dependence for modeling the relationship between the distance from the landfill boundary and the total coverage of the tree trunk with lichens. The results of the analysis confirmed the correctness of the use of the aforementioned method. The relationship between the results obtained by the lichen indication method and the strength of the odor from the landfill was evaluated. Based on the results of calculating the relative values of the assessment of atmospheric air pollution by the method of coverage of the tree trunk with lichens and the strength of the odor, a regression analysis was carried out and mathematical relationships were determined, that most accurately describe the change in these indicators with distance from the landfill boundary. It is proved that both tested methods can be used in Ukrainian realities to monitor the state of atmospheric air in the area of influence of municipal landfills, depending on the purpose of research. The analysis of the research results confirmed the significance of the results of the obtained assessment of the impact of the Zhytomyr solid waste landfill on the state of atmospheric air. The materials of these studies can find further application for the formation of databases of knowledge of landfills, which will allow to develop a strategy for managing them as an object of increased environmental hazard.
\end{abstract}

Keywords: landfill, landfill gas, odor, bioindication, lichen indication, lichens

\section{INTRODUCTION}

The functioning of human society is inextricably linked with the formation and accumulation of solid waste, among which a particular environmental hazard is posed by landfills for mining and chemical waste (Gorova et al., 2013, Pavlychenko \& Kovalenko, 2013) and municipal waste (Malovanyy et al., 2019, Skyba et al., 2020, Tymchuk et al., 2020). The uncontrolled accumulation of solid municipal waste is especially dangerous.
Since the 90s of the twentieth century, the study of the impact of municipal solid waste landfills on the state of the environment has received a lot of attention from scientists in most countries of the world. According to The 1st Waste Atlas Report, almost $40 \%$ of the world's waste is found in open landfills, most of which are located near urban areas, posing a great threat to human health and the environment (Waste Atlas Report, 2013).

Hundreds of thousands of tons of municipal waste are accumulated annually in urban 
landfills, even in an average city. When decomposing, they poison the air, soil, groundwater and thus pose a serious threat to the environment and humans. In 2014, Waste Atlas The World's 50 Biggest Dumpsites visualized data (the study used 59,000 files from 25 countries, collected through crowdsourcing) on the world's biggest landfills. The report shows that the world's 50 biggest landfills affect the lives of 64 million people every day (Waste Atlas The World's 50 Biggest Dumpsites, 2014).

Over the past decades, the global amount of municipal solid waste has been increasing by $3-6 \%$ annually. In 2000, Ukraine generated an average of $180 \mathrm{~kg}$ of municipal solid waste per capita, in 2010 this figure increased to $270 \mathrm{~kg}$, in 2019 the annual amount of waste per capita is about $300 \mathrm{~kg}$ and tends to increase.

Despite the fact that the specific indicators of waste generation in Ukraine are still significantly lower than the European average (about $503 \mathrm{~kg}$ per capita per year) and lower than the indicators of the new EU member states (420 kg per capita), in 2017 Ukraine was in 9th place in the ranking of countries with the highest amount of garbage per capita according to the American agency 24/7 Wall Street (Byrnes \& Frohlich, 2019).

A typical scheme for the management of municipal solid waste in Ukraine is their indivisible collection and disposal (>90\%). In 2014, Ukraine set itself the goal of harmonizing its national legislation in the field of solid waste management with European standards. It is planned to implement the EU Directives on waste management, which regulate waste management in European countries, provide a clear sequence of actions to be taken with waste, classify waste, set a strategic goal to reduce the amount of waste that is taken to landfills. (Mishchenko et al., 2013, Omelyanenko \& Makovetska, 2015, Getman \& Lozo, 2017).

However, at present the problem of landfills remains relevant for Ukraine, as the total amount of waste accumulation in Ukraine is about 30 billion tons, and about 160 thousand hectares of land are occupied by waste. And this is one of the highest rates of waste accumulation in the world. Municipal solid waste is disposed at more than 6,700 landfills and dumps with a total area of about 9 thousand hectares (Popovych, 2019). The majority of landfills operate in overload mode, i.e. with a significant violation of design indicators for the volume of waste accumulation, causing considerable environmental pollution in the area affected by landfills (Popovych et al., 2018, Popovych et al., 2020). In Ukraine, 10 years ago (Radovenchyk \& Gomel, 2010) almost 6\% of facilities were overloaded, and $15.3 \%$ did not meet environmental safety standards. Today, their location, equipment and conditions do not meet regulatory requirements, which increases the environmental hazard of these facilities. They are equipped without modern engineering and environmental requirements, so such landfills can be potentially dangerous for both the environment and human health (Korbut, 2015).

Due to the variety of garbage entering landfills and dumps, it is quite difficult to assess the chemical composition of the stored waste; the formation of a significant amount of toxic leachate and gases capable of spontaneous combustion occur in its thickness, as well as the development of pathogens (Korbut \& Malovanyy, 2013, Sagdeeva et al. 2018).

Landfills and especially landfills for municipal solid waste are powerful sources of pollution of the atmosphere, hydrosphere and soil (Osipova \& Remez, 2015, Vambol et al., 2017). Free exit of landfill gas into the environment causes a number of negative consequences, in particular, it leads to the pollution of the atmosphere of the surrounding territories with toxic compounds, which, moreover, have an unpleasant odor (Stalinska, 2016, Safranov et al., 2016).

Studies have shown that the main odorous substances emitted from the landfills are styrene, toluene, xylene, acetone, methanol, n-butanone, n-butylaldehyde, acetic acid, dimethyl sulfide, dimethyl disulfide and ammonia (Fang et al., 2012; Wu C et al., 2018).

More than 50 NMVOCs have been identified in untreated landfill gas (sulfur compounds led to the greatest increase in odor strength) (Liu et al., 2015, Pecorini et al., 2017, Rossi et al., 2018, Pecorini et al., 2020, US EPA, 2021).

This causes complaints from people who live nearby about the unpleasant smell, as well as health problems. The odor can be irritating, even if the odorous substance is not hazardous to health. The gas and unpleasant smells from landfills spread to a distance of up to 300-400 meters. If the landfill is located near a residential area, conflicts often arise, since the smell of the landfill significantly worsens the living conditions of people (Stolaroff et al., 2012, Sagdeeva 2018; Lee et al., 2018). 
Monitoring of the impact of landfills on the environment is a modern form of implementing the processes of environmental activity using informatization means. It provides regular assessment and forecasting of the state of the society living environment and the conditions for the functioning of ecosystems for making management decisions on environmental safety, preserving the natural environment and rational use of natural resources.

The process of monitoring and assessing the state of the environment is considered as a sequence of interrelated actions, starting with the identification of information needs and ending with the use of the obtained information product. Evaluation of the obtained information can lead to the determination of new needs or to the revision of existing ones, starting a new sequence of actions.

Assessment of the degree of environmental hazard using the human sensory system is probably the most subjective, however, taking odor measurements can allow you to objectively assess the real extent of the problem (Cheng et al., 2019).

After the indication of environmental hazards using the human sensory system, there is an important task to make an integrated assessment of atmospheric air, which can be obtained using biological methods, due to the ability of bioindicators to comprehensively characterize the diversity of pollutants (Manning \& Feder 1985, Badtiyev \& Kulemin, 2001).

Lichens were chosen as bioindicators. The reason for the increased vulnerability of lichens to atmospheric pollution is in the anatomical, morpho-physiological features of the symbiont. Lichens are characterized by a long life span, the absence of gas and water exchange organs and, as a result, little ability to self-regulate due to the absence of protective barriers and a great dependence on the physicochemical properties of the environment. The positive qualities regarding the assessment of the degree of pollution, in addition to those listed, include: speed of diagnosis and its low cost; due to their high prevalence-the ability to cover large territories; integral assessment of the result of long-term action of anthropogenic pollution (Trass, 1973, Trass, 1985, S. Ya. Kondratyuk, 2016).

The aim of the study was to introduce monitoring of the impact of landfills on the atmospheric air using bioindication methods on the example of the Zhytomyr landfill (Ukraine). A comprehensive study of atmospheric air pollution in the landfill area has been carried out using a human sensor system and an integral assessment by means of bioindication.

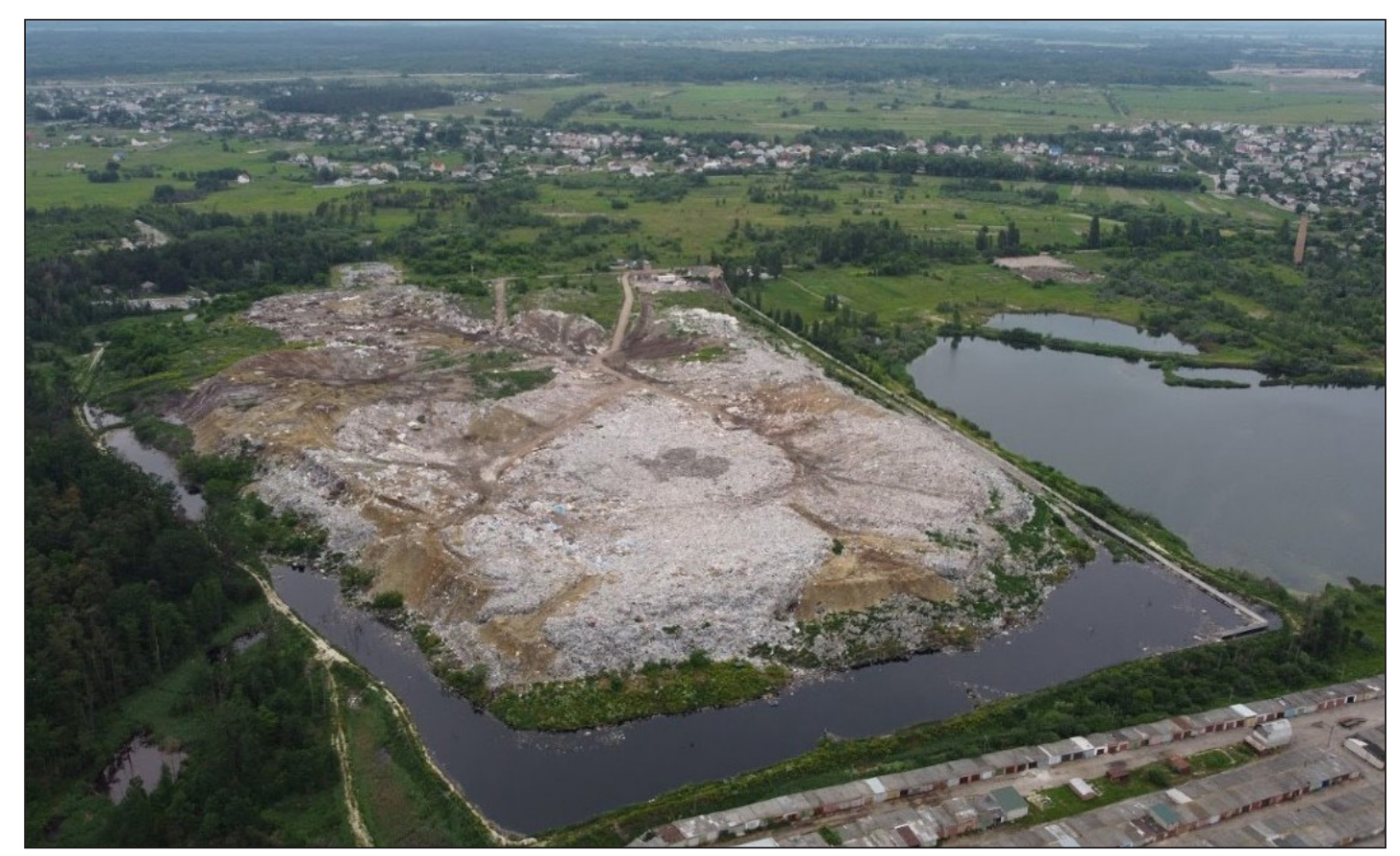

Fig. 1. View of the municipal landfill for solid waste disposal (materials used from the site https://www.google.com/maps; coordinates: 50.3045596,28.6414298) 


\section{MATERIALS AND METHODS}

The object of the study was the solid waste landfill in the city of Zhytomyr (Ukraine)-one of the typical Ukrainian landfills, which is operated with minimal implementation of environmental protection measures.

All municipal waste of the city is disposed of without prior sorting at the landfill (Fig. 1.), which has become a source of intense pollution of the atmosphere, groundwater, and in general - a threat of an epidemic state and requires improvement of the waste disposal process. The municipal solid waste landfill has been in operation since 1957, its total area is 21.6 hectares. The solid waste landfill was established on the site of the Kroshensky brick factory quarry, spontaneously, without a project. At the time of its commissioning, the requirements for the existence of the project were not legally regulated. This situation is typical for many cities in the country. Every year about $500,000 \mathrm{~m}^{3}$ of municipal solid waste is accumulated at the landfill. The total amount of waste buried at the landfill is $145,000,000 \mathrm{~m}^{3}$.

The geographical location of the solid waste landfill in the city of Zhytomyr is quite specific (Fig. 2.) and allows a variety of comprehensive research; the shortest distance of the land plot from: city limits $-0.65 \mathrm{~km}$; residential and public buildings $-0.514 \mathrm{~km}$; agricultural lands $0.05 \mathrm{~km}$; forest plantation (forest) $-0.05 \mathrm{~km}$; the Kroshenka River (left tributary of the Kamyanka River, which in turn is a left tributary of the
Teteriv River) - 1200 m; adjacent to the quarry of Kroshensky brick factory.

To evaluate the intensity of odor in the zone of influence of municipal solid waste landfills, the statistical method ASTM E544 (ASTM E544-18) was chosen, which is used to quantitatively express the intensity of the smell of a substance or environment by comparing it with the so-called "static scale»; the method was tested for the first time in Ukraine.

ASTM E544 was first published in 1975 as a method to evaluate odor intensity utilizing references as anchors on the scale. N-butanol was chosen and utilized as the reference scale due to its availability and generally neutral hedonic tone (not overly pleasant or unpleasant). The standard practice allows for two methods for a reference scale: 1) static and 2) dynamic. The static method utilizes specific aqueous solutions of n-butanol in jars or flasks for the assessors to reference. The dynamic method allows for use of an olfactometer device to present reference concentrations of n-butanol in air. The ASTM International Standard Practice for evaluation of odor intensity with n-butanol reference has been revised and published in October 2018 as ASTM E544-18. The ASTM Committee E18 on Sensory Evaluation of Materials and Products has recently published a revision of ASTM E544. A few major edits were made, but basic principles of the method remained unchanged.

The smell of the sample was compared, rejecting the qualitative characteristic of the smell,

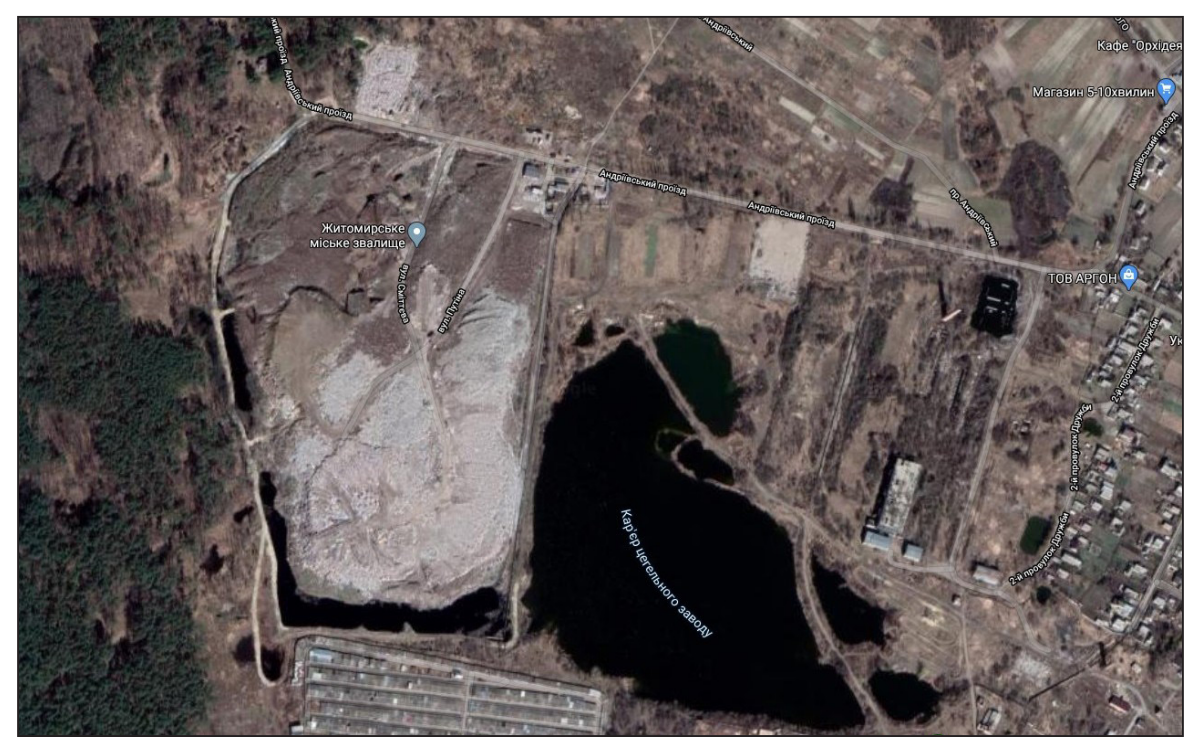

Fig. 2. Visualization of the geographical location of the solid waste landfill in the city of Zhytomyr (Ukraine), materials from the site https://www.google.com/maps; coordinates: 50.303163,28.6426183,1012 
in intensity with the scale of prepared solutions by 8 independent assessments. The evaluators reported a point on the scale the odor intensity of which was closest to that of the sample. Independent evaluations were statistically processed and calculated, the overall result was reported as the concentration in ppm of 1-butanol in water.

Solutions of 1-butanol in water were prepared using pipettes and flasks applying standard laboratory methods of solution preparation. The solutions were placed in $500 \mathrm{ml}$ Erlenmeyer wideneck conical flasks. The volume of the solutions was $200 \mathrm{ml}$ and was replaced with fresh solution after a maximum of 2 hours. Between odor assessments, the flasks were covered with aluminum foil to ensure the state of balance between the solutions and the free volume of the flasks. The flasks were gently shaken by each evaluator before evaluating the odor to achieve the balance. The temperature of the reference solutions during the test was background (did not differ much from the ambient temperature), was noted in the report and was kept constant during the test.

The detection limit of 1-butanol odor in water is $2.5 \mathrm{ppm}$ (hereinafter, the concentration is indicated in ppm-parts per million, based on volume, $1 \mathrm{ppm}=1 \mu \mathrm{L} / 1 \mathrm{~L}$ ) at $210 \mathrm{C}$. The beginning of the scale took higher concentrations; the top of the scale did not reach 70,800 ppm-the solubility limit of butanol in water at $300^{\circ} \mathrm{C}$. The most useful concentration range is between 10 and $20,000 \mathrm{ppm}$. This interval was covered by using 12 flasks with solutions in which the concentration changed exponentially with the factor of 2-in the first flask the concentration was $10 \mathrm{ppm}$, in the second -20 , etc. The scale points (flasks with solutions) were stored in a systematic order, in ascending order of concentration and numbered from 1 for the lowest concentration of butanol and above. The points of correspondence of the sample odor to the scale were indicated by the scale numbers (flask numbers), the positions between the points of the scale (if the odor was stronger than the odor of one of the points on the scale and weaker than the odor of the next point) or points that were higher than the scale endpoints (when the odor of the sample was less intense than the odor of the lowest point of the scale or more intense than the odor of the highest point).

Calculation of the final result:

1. The results of all evaluators were converted from scale points to ppm of 1-butanol. If the value was not integer (for example, the odor was on a scale between 7 and 8), then the geometric mean was taken between the concentrations corresponding to the highest and lowest point.

2. The geometric mean of the results of all evaluators was determined. For this purpose, the logarithms of all results in ppm were taken, the arithmetic mean of them was found, and then the antilogarithm of the obtained arithmetic mean was taken.

3. The standard deviation for the logarithms of the concentrations was determined.

At the same time, the optimal (from the point of view of the research goal) method of bioindication was chosen-the determination of atmospheric air pollution based on the evaluation of the projective coverage of the trunk with lichens, which allowed to transfer the research from the descriptive plane to a mathematical basis.

The studies analyzed the prevalence of the following types of lichens: scale - Graphis ( $\mathrm{Gra}$ phis scripta (L.) Ash.) and Xanthoria (Xanthoria elegans); leafy - Hypogymnia (Hypogymnia) and Parmelia (Parmelia); bushy - Cladonia (Cladonia) and Usnea (Usnea).

At the selected sites (at a distance of $500 \mathrm{~m}$, $400 \mathrm{~m}, 300 \mathrm{~m}, 200 \mathrm{~m}$ and $100 \mathrm{~m}$ from the landfill boundary), all species of well-lit, separately growing deciduous trees were surveyed. Lichens were described at a height of 1.5-2.0 m from the soil surface, as well as at the base of trees (phorophytes) from the genera poplar, maple, willow, ash, birch, and others. Two more sites were also examined: a control site in the recreational area of the city and a site at a distance of 1000 meters from the landfill. A total of 10 old but healthy trees growing separately were examined. The month of November was chosen for the study. Using the method of zoning the purity of the air according to lichens and the point scale of the projective cover of the tree trunk, the level of air pollution for each site was determined (Krasnogorskaya et al. 2004).

In the course of the study, the degree of tree trunk coverage with lichens was calculated, and such indicators were determined: the average percentage of each lichen species (for a deeper and more detailed analysis), the total percentage of tree trunk coverage, the dominant species and its number. Based on the data obtained, the area was determined according to a 5-point scale of the projective coverage of the tree trunk (Table 1). 
Table 1. Evaluation of the frequency of distribution and the degree of coverage of lichens on a five-point scale

\begin{tabular}{|l|c|c|c|c|}
\hline \multicolumn{2}{|c|}{ Frequency of distribution } & \multicolumn{2}{c|}{ Degree of coverage } & Points \\
\hline Very rarely & $<5 \%$ & Very low & $<5 \%$ & 1 \\
\hline Rarely & $5-20 \%$ & Low & $5-20 \%$ & 2 \\
\hline Rarely & $20-40 \%$ & Medium & $20-40 \%$ & 3 \\
\hline Often & $40-60 \%$ & High & $40-60 \%$ & 4 \\
\hline Very often & $60-100 \%$ & Very high & $60-100 \%$ & 5 \\
\hline
\end{tabular}

After processing all the data, the areas under study were distributed according to a 5-point scale of the projective coverage of the tree trunk and according to the degree of air pollution. We also performed statistical processing, comparison of results and correlation.

\section{RESULTS AND DISCUSSION}

The first stage of the study was to evaluate the odor and determine the dependence of its intensity on the distance to the object of study. In the area under study, the western wind direction prevails $-18.5 \%$ (Figure 3 ). It is from the leeward side that the strongest smell is observed, which brings discomfort to the local population (in addition, residential and public buildings are located to the east of the landfill).

The first point for assessing the odor in the impact zone of the landfill was laid at a distance of $500 \mathrm{~m}-$ on the boundary of the sanitary

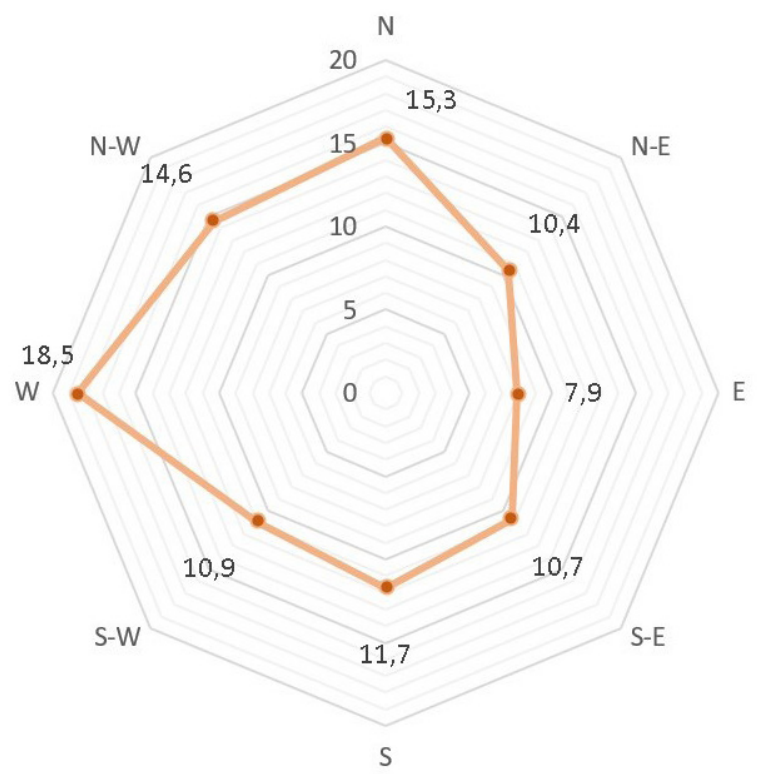

Fig. 3. Wind rose of the location of the object of study with average values (Zhytomyr, Ukraine) https://world-weather.ru/archive/ukraine/zhytomyr protection zone (State building codes of Ukraine, 2005), others - every 100 meters to the landfill (a total of 6 points). We were moving along Andriyivskyi Proyizd Street in the direction of the landfill (Figure 4). For each point of the study, its coordinates were determined using www.google. $\mathrm{ru} /$ maps (Table 2).

At each of the selected points according to the ASTM E544 method, eight independent evaluators performed an assessment of the odor, rejecting the qualitative characteristic of the odor (only by intensity). Each expert determined the strength of the odor using samples in flasks labeled 1-12 (on a scale of prepared solutions - Table 3 ). The results of the study and their statistical analysis are grouped in Table 4.

Using the odor intensity scale the final result for each point was calculated. The results of the study are grouped in Table 5. To confirm the reliability of the results, an evaluation of the smell of odorous gases in the solid waste landfill was also performed and such result was obtained: $18766,142 \mathrm{ppm}$-the corresponding odor in the concentration of n-butanol, ppm.

In order to process the obtained results, the method of regression analysis was chosen, which is relevant in ecology. Regression statistics showed that the coefficient of determination is equal to 0.99 , which characterizes the quality of the obtained regression line. Since the coefficient of determination is higher than $80 \%$, the model can be considered valid.

Based on the calculations, an exponential dependence (Figure 5) was found to model the interdependence between the distance from the gas source (landfill in Zhytomyr) and the odor intensity.

$$
\begin{gathered}
y=7890.8 e^{-0.01 x} \\
R^{2}=0.9987
\end{gathered}
$$

The results of the analysis confirmed the correctness of using the above method.

After the experiment, a natural question arose: is the presence of odor an indicator of air 


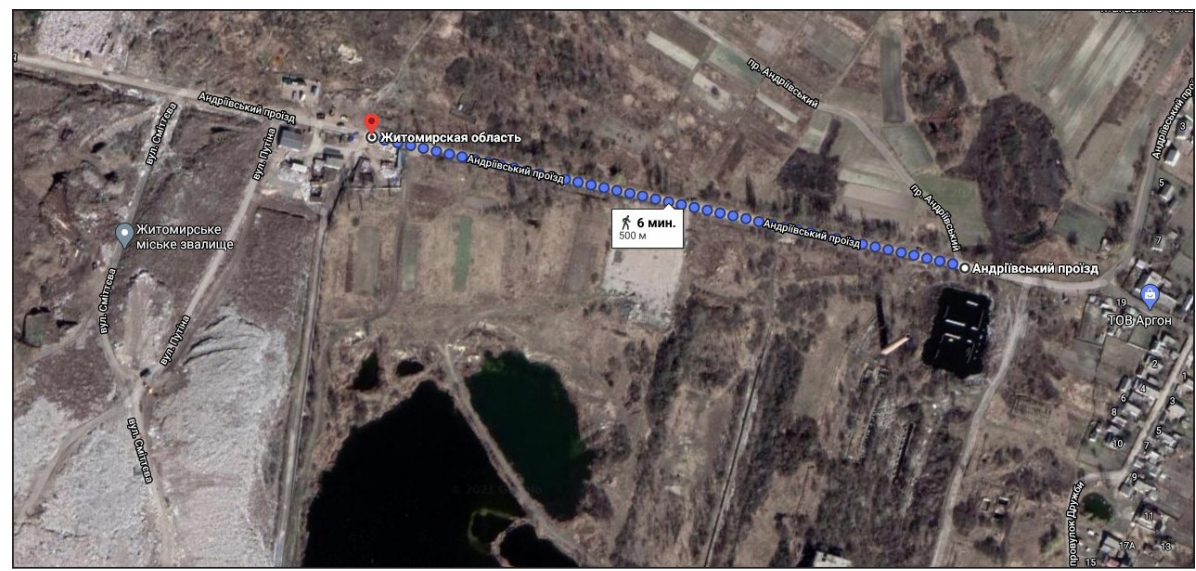

Fig. 4. The direction of movement during the study of odor in the area of influence of the landfill

Table 2. Coordinates of study points during the assessment of odor in the area of influence of the landfill

\begin{tabular}{|c|c|c|c|}
\hline $\begin{array}{c}\text { Number of the study } \\
\text { point }\end{array}$ & $\begin{array}{l}\text { Distance from the boundary } \\
\text { of the landfill, } m\end{array}$ & Degrees and decimal minutes & Degrees, minutes and seconds \\
\hline 1 & 500 & $50.30443,28.65130$ & $50^{\circ} 18^{\prime} 16.0 » \mathrm{~N} 28^{\circ} 39^{\prime} 04.7 » \mathrm{E}$ \\
\hline 2 & 400 & $50.30466,28.64954$ & $50^{\circ} 18^{\prime} 16.8 » \mathrm{~N} 28^{\circ} 38^{\prime} 58.3 » \mathrm{E}$ \\
\hline 3 & 300 & $50.30484,28.64839$ & $50^{\circ} 18^{\prime} 17.4 » \mathrm{~N} 28^{\circ} 38^{\prime} 54.2 » \mathrm{E}$ \\
\hline 4 & 200 & $50.30502,28.64693$ & $50^{\circ} 18^{\prime} 18.1 » \mathrm{~N} 28^{\circ} 38^{\prime} 49.0 » \mathrm{E}$ \\
\hline 5 & 100 & $50.30521,28.64561$ & $50^{\circ} 18^{\prime} 18.8 » \mathrm{~N} 28^{\circ} 38^{\prime} 44.2 » \mathrm{E}$ \\
\hline 6 & 0 & $50.30544,2864409$ & $50^{\circ} 18^{\prime} 19.6 » \mathrm{~N} 28^{\circ} 38^{\prime} 38.7 » \mathrm{E}$ \\
\hline
\end{tabular}

pollution in the area affected by the landfill? Is there a relationship between the strength of the stench from the landfill and air pollution and, most importantly, what signs can be used to assess the extent of landfill gas pollution.

The composition of landfill gas depends on many factors: season, climatic zone, air temperature and humidity, features of design and operation of the landfill, its age and the composition of garbage that enters the landfill. However, the potential danger of the object of study in terms of

Table 3. Correspondence of n-butanol concentrations to the scale of odor intensity determination

\begin{tabular}{|c|c|c|c|}
\hline $\begin{array}{c}\text { Sample of } \\
\text { odor }\end{array}$ & $\begin{array}{c}\text { N-butanol concentration, } \\
\text { ppm }\end{array}$ & $\begin{array}{c}\text { Scale } \\
\text { point }\end{array}$ & $\begin{array}{c}\mathrm{Lg} \\
(\mathrm{ppm})\end{array}$ \\
\hline 1 & 10 & 1 & 1 \\
\hline 2 & 20 & 2 & 1.301 \\
\hline 3 & 40 & 3 & 1.602 \\
\hline 4 & 80 & 4 & 1.903 \\
\hline 5 & 160 & 5 & 2.204 \\
\hline 6 & 320 & 6 & 2.505 \\
\hline 7 & 640 & 7 & 2.806 \\
\hline 8 & 1280 & 8 & 3.107 \\
\hline 9 & 2560 & 9 & 3.408 \\
\hline 10 & 5120 & 10 & 3.709 \\
\hline 11 & 10240 & 11 & 4.01 \\
\hline 12 & 20480 & 12 & 4.311 \\
\hline
\end{tabular}

assessment of atmospheric air is its unpredictability: it is too difficult to estimate and, moreover, to predict the composition of landfill gas, because the composition and amount of garbage entering the landfill is not controlled. Also, frequent uncontrolled fires and imperfect technology of burning of untreated landfill gas create problems with toxic combustion products: primarily with sulfur dioxide (when burning hydrogen sulfide). However, according to the "Methodology for the Development of Environmental Impact Assessment for Solid Waste Management Facilities", it is currently recommended in Ukraine to investigate the presence of only a few harmful gases that have an unpleasant odor, pollute the air and create a fire hazard, namely $\mathrm{CH}, \mathrm{NH}, \mathrm{HS}, \mathrm{CO}, \mathrm{PH}$.

According to the authors, the actual research method in this case is bioindication-a comprehensive assessment of the intensity and consequences of long-term environmental pollution by the presence of indicator organisms, taxonomic composition of cenoses or deviations in the normal development of organisms.

Lichens deserve special attention in terms of the purpose of the study, being a sensitive indicator of general air pollution due to their structure. Since they have no integumentary tissue and are hygroscopic due to mycelium, the algal 
Table 4. The results of odor assessment of in the area of influence of the object of study

\begin{tabular}{|l|c|c|c|c|c|c|c|}
\hline \multicolumn{1}{|c|}{ Odor assessment results } & $500 \mathrm{~m}$ & $400 \mathrm{~m}$ & $300 \mathrm{~m}$ & $200 \mathrm{~m}$ & $100 \mathrm{~m}$ & $\begin{array}{c}\text { Landfill } \\
\text { boundary }\end{array}$ & Landfill \\
\hline Result 1 & 4 & 5 & 6 & 8 & 10 & 12 & 12 \\
\hline Result 2 & 3 & 6 & 8 & 8 & 9 & 10 & 11 \\
\hline Result 3 & 4 & 5 & 6 & 8 & 9 & 10 & 12 \\
\hline Result 4 & 3 & 4 & 4 & 6 & 8 & 10 & 12 \\
\hline Result 5 & 4 & 6 & 7 & 9 & 9 & 11 & 12 \\
\hline Result 6 & 3 & 5 & 7 & 9 & 9 & 11 & 12 \\
\hline Result 7 & 3 & 6 & 8 & 7 & 10 & 10 & 11 \\
\hline Result 8 & 4 & 4 & 6 & 8 & 9 & 11 & 12 \\
\hline Arithmetical mean & 3.500 & 5.125 & 6.500 & 7.875 & 9.125 & 10.625 & 11.750 \\
\hline Dispersion & 0.2857 & 0.6964 & 1.7143 & 0.9821 & 0.4107 & 0.5536 & 0.2143 \\
\hline Arithmetic mean error & 0.1890 & 0.2950 & 0.4629 & 0.3504 & 0.2266 & 0.2631 & 0.1637 \\
\hline Accuracy of the experiment, \% & 5.4 & 5.8 & 7.1 & 4.4 & 2.5 & 2.5 & 1.4 \\
\hline
\end{tabular}

Table 5. The results of the study to assess the strength of the odor in the area affected by the solid waste landfill (concentration of n-butanol, ppm)

\begin{tabular}{|c|c|c|}
\hline № of point & $\begin{array}{c}\text { Distance from } \\
\text { the landfill } \\
\text { boundary, } \mathrm{m}\end{array}$ & $\begin{array}{c}\text { Correspondence } \\
\text { to } \text {-butanol } \\
\text { concentration, } \mathrm{ppm}\end{array}$ \\
\hline 1 & 500 & 56.56 \\
\hline 2 & 400 & 174.43 \\
\hline 3 & 300 & 452.376 \\
\hline 4 & 200 & 1173.208 \\
\hline 5 & 100 & 2790.134 \\
\hline 6 & 0 & 7890.872 \\
\hline Control (landfill) & - & 18766.142 \\
\hline
\end{tabular}

component is extremely sensitive to air pollution (especially by sulfur dioxide). Lichens, especially epiphytes, are the most sensitive indicator of general air pollution, as they are nourished directly from the environment-from precipitation, dew, fog, and dust that settle on «thallus.» The average age of lichens is from 30 to 80 years, for some-a few hundred years, but they grow very slowly-1-8 mm per year.

Lichens have been selected for global monitoring due to their sensitivity, low variability (compared to other organisms), widespread distribution and long lifespan. The most informative are the methods of lichen indication in the study of large areas and the presence of a powerful source of air pollution.

The location of the research object facilitates the research through lichen indication-many deciduous trees grow around the landfill. The authors chose a method for determining air pollution based on the assessment of the projective coverage of the trunk with lichens (which is allowed by the location of the object of study).

At different distances from the landfill, all species of well-lit, separately growing deciduous trees were examined. Lichens were described at a height of 1.5-2.0 $\mathrm{m}$ from the soil surface, as well as at the base of trees (phorophytes) from

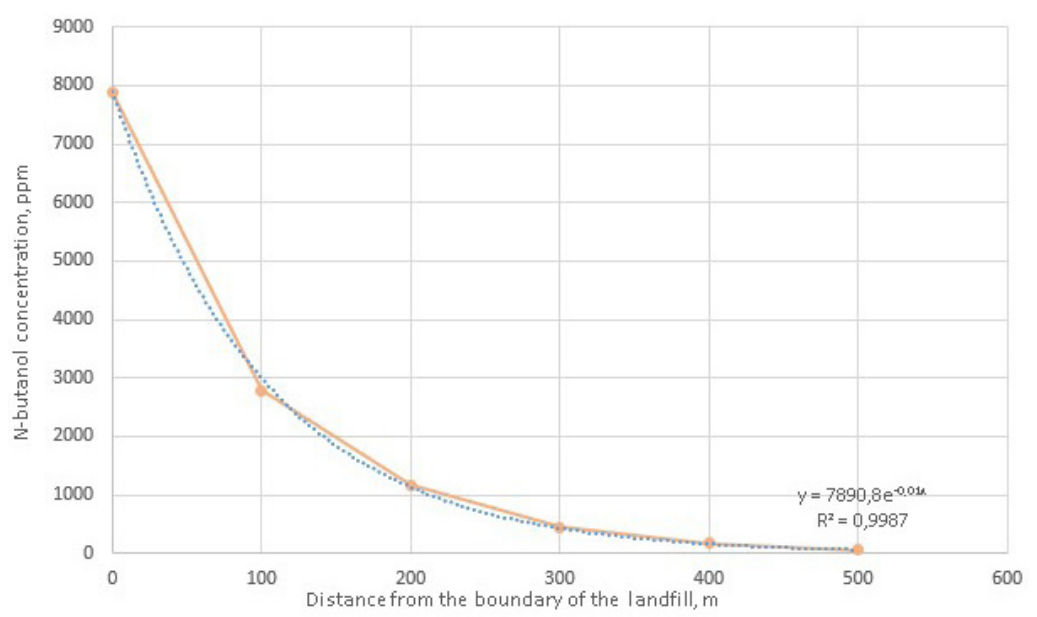

Fig. 5. The results of the study to assess the intensity of odor in the area affected by the solid waste landfill 
the genera poplar, maple, willow, ash, birch, and others. A total of 10 old but healthy trees growing separately were examined. The research was conducted in November 2020, the results of the study are grouped in Table 6

Lichens are constantly negatively affected, which is confirmed by their decrease in the experimental areas. By the decrease in the number of lichens, one can judge the extent of stress in the zone of influence of the research object.

According to the degree of sensitivity to anthropogenic factors, there are 10 classes of poleotolerance (H.H. Trass, 1985): the species belongs to the class, under anthropogenic conditions of which it is most often found, has high indicators of coverage and vitality, ie, it is an indicator of these conditions. The analysis of the species composition of lichens and their comparison with the classes of poleotolerance and habitat types of epiphytic lichens confirmed the correctness of this method: when approaching the landfill, the number of lichen species decreased. From a distance of 100 meters and closer only Graphis (Graphis scripta (L.) Ash.) could be seen on the trees.

Using the method of zoning the purity of air by lichens and the point scale of projective coverage of the tree trunk, the level of air pollution was determined for each area. After processing all the data, the studied areas were distributed on a 5-point scale of projective tree trunk coverage and the degree of air pollution (Table 7).

Based on the obtained data, only the control area (which was laid in the residential area) and the area located at a distance of $1000 \mathrm{~m}$ from the landfill are clean.
In order to process the obtained results, the method of regression analysis was chosen to assess the dependence of the total degree of lichen tree coverage on the distance from the landfill boundary. Regression statistics showed that the coefficient of determination is equal to 0.87 . The type of the obtained dependence is presented in Figure 6.

$$
\begin{gathered}
y=15.507 \mathrm{e}^{0.0022 x} \\
\mathrm{R}^{2}=0.8748
\end{gathered}
$$

Based on the calculations, an exponential dependence was found for modeling the interdependence between the distance from the landfill boundary to the general degree of lichen coverage of a tree trunk. The results of the study confirmed the correctness of using the abovementioned method.

A zoning was carried out by the air pollution in the area of influence of the solid waste landfill in the city of Zhytomyr, the analysis of which indicates a clear trend in relation to atmospheric air pollution in the vicinity of the solid waste landfil. It allowed to draw a conclusion about the possibility of using this bioindication method to study the state of atmospheric air in the process of monitoring solid waste landfills, which is not only ecologically expedient, but also more optimal in terms of cost, in comparison with existing instrumental methods.

We performed an analysis of the relationship between the results obtained by the lichen indication method and the strength of the odor from the landfill. For the convenience of comparing

\begin{tabular}{|c|c|c|c|c|c|c|c|c|}
\hline Indicators & control & $1000 \mathrm{~m}$ & $500 \mathrm{~m}$ & $400 \mathrm{~m}$ & $300 \mathrm{~m}$ & $200 \mathrm{~m}$ & $100 \mathrm{~m}$ & $0 \mathrm{~m}$ \\
\hline Result 1 & 87 & 77 & 57 & 44 & 31 & 22 & 12 & 1 \\
\hline Result 2 & 77 & 77 & 54 & 44 & 33 & 21 & 12 & 1 \\
\hline Result 3 & 84 & 79 & 58 & 43 & 32 & 23 & 11 & 0 \\
\hline Result 4 & 89 & 74 & 56 & 44 & 30 & 20 & 11 & 1 \\
\hline Result 5 & 82 & 79 & 54 & 45 & 34 & 21 & 11 & 2 \\
\hline Result 6 & 84 & 76 & 58 & 43 & 32 & 19 & 12 & 1 \\
\hline Result 7 & 81 & 74 & 56 & 42 & 33 & 22 & 13 & 0 \\
\hline Result 8 & 82 & 72 & 57 & 41 & 32 & 21 & 11 & 1 \\
\hline Result 9 & 79 & 79 & 54 & 42 & 33 & 22 & 12 & 1 \\
\hline Result 10 & 85 & 77 & 56 & 42 & 30 & 19 & 13 & 2 \\
\hline Arithmetical mean & 83.000 & 76.400 & 56.000 & 43.000 & 32.000 & 21.000 & 11.800 & 1.000 \\
\hline Dispersion & 12.8889 & 5.8222 & 2.4444 & 1.5556 & 1.7778 & 1.7778 & 0.6222 & 0.4444 \\
\hline Arithmetic mean error & 1.2693 & 0.8531 & 0.5528 & 0.4410 & 0.4714 & 0.4714 & 0.2789 & 0.2357 \\
\hline Accuracy of the experiment, \% & 1.5 & 1.1 & 1.0 & 1.0 & 1.5 & 2.2 & 2.4 & 23.6 \\
\hline
\end{tabular}

Table 6. Projective coverage of tree trunks in the studied areas 
Table 7. The degree of air pollution in the area of influence of the landfill in Zhytomyr by the projective coverage of the tree trunk with lichens

\begin{tabular}{|c|c|c|c|}
\hline Analysis of the state of lichen coverage & $\begin{array}{l}\text { Evaluation of } \\
\text { the degree of } \\
\text { coverage on a } \\
\text { 5-point scale }\end{array}$ & $\begin{array}{l}\text { Distance from } \\
\text { the boundary } \\
\text { of the landfill, } \\
\text { m }\end{array}$ & $\begin{array}{c}\text { The general } \\
\text { degree of } \\
\text { coverage of a } \\
\text { tree trunk by } \\
\text { lichens, } \%\end{array}$ \\
\hline \multirow{2}{*}{$\begin{array}{l}\text { All types of lichens are present, Graphis (Graphis scripta (L.) Ach.), } \\
\text { Xanthoria (Xanthoria elegans), Hypogymnia (Hypogymnia), Parmelia } \\
\text { (Parmelia), Cladonia (Cladonia), Usnea (Usnea) }\end{array}$} & \multicolumn{3}{|c|}{ Clean air } \\
\hline & 5 & control & 83.0 \\
\hline \multirow{2}{*}{$\begin{array}{l}\text { All types of lichens are present, decrease in the number of bushy lichens, } \\
\text { Graphis (Graphis scripta (L.) Ach.), Xanthoria (Xanthoria elegans), } \\
\text { Hypogymnia (Hypogymnia), Parmelia (Parmelia), Cladonia (Cladonia) }\end{array}$} & \multicolumn{3}{|c|}{ Relatively clean air } \\
\hline & 5 & 1000 & 76.4 \\
\hline \multirow{2}{*}{$\begin{array}{l}\text { Graphis (Graphis scripta (L.) Ach.), Xanthoria (Xanthoria elegans), } \\
\text { Hypogymnia (Hypogymnia) }\end{array}$} & \multicolumn{3}{|c|}{ Polluted air } \\
\hline & 4 & 500 & 56.0 \\
\hline \multirow{4}{*}{ Graphis (Graphis scripta (L.) Ach.), Xanthoria (Xanthoria elegans) } & \multicolumn{3}{|c|}{ Heavily polluted air } \\
\hline & 3 & 400 & 35.4 \\
\hline & 3 & 300 & 25.2 \\
\hline & 3 & 200 & 20.5 \\
\hline \multirow{3}{*}{ Graphis (Graphis scripta (L.) Ach.) } & \multicolumn{3}{|c|}{ Too heavily polluted air } \\
\hline & 2 & 100 & 19.5 \\
\hline & 2 & 0 & 18.2 \\
\hline
\end{tabular}

methods, the indicators were brought into one mathematical plane. The strength of the odor was expressed as a percentage. The odor strength at the landfill-the strongest odor (corresponding to n-butanol - 18766.142 ppm)-was taken as $100 \%$, after which the odor strength was calculated proportionally in percentage in other studied points (according to the table "The results of the study to assess the strength of the odor in the area affected by the solid waste landfill (concentration of n-butanol, ppm)").

Also the concept of «the degree of non-coverage of the tree trunk by lichens» was introduced, which is also interpreted as a percentage (from the possible one hundred percent the percentage of tree trunk coverage by lichens at each study point was subtracted). The next step in generalizing the results for comparison was the introduction of a relative scale «relative non-coverage of the tree trunk by lichens», where for a distance of $0 \mathrm{~m}$ a conditional value of $100 \%$ was taken, and a relative scale «relative odor», where also for a distance of $0 \mathrm{~m}$ a conditional value of $100 \%$ was taken. The results of the calculations are given in Table 8.

Based on the results of calculating the relative values of atmospheric pollution evaluation by the method of coverage of the tree trunk with lichens and the strength of odor, regression analysis was performed and mathematical dependences

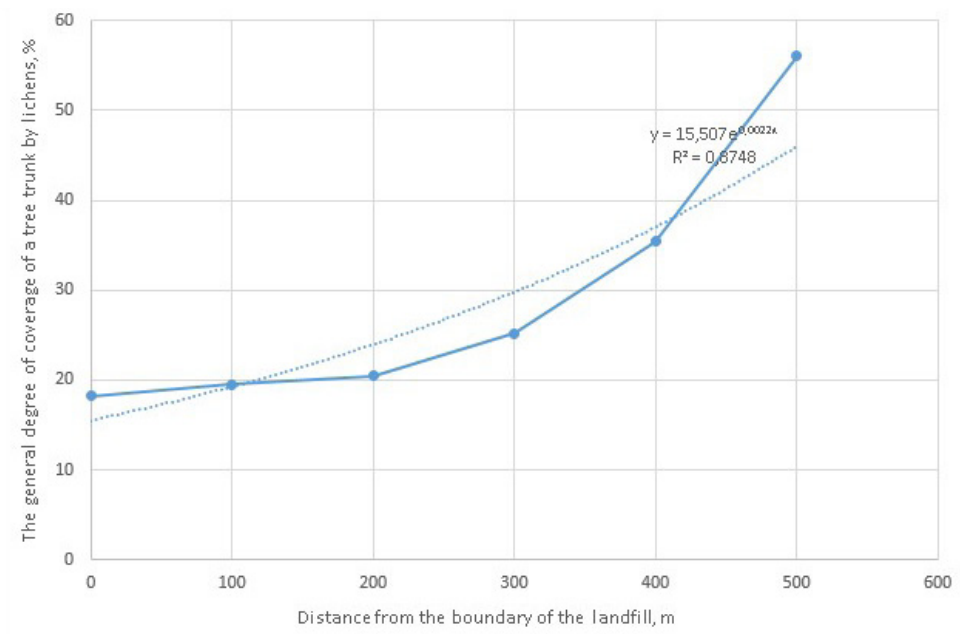

Fig. 6. Dependence of the general degree of coverage of a tree trunk by lichens $(\%)$ on distance to a landfill border (m) 
Table 8. The results of comparisons (\%) of the evaluation of air pollution by the method of coverage of the tree trunk with lichens and the strength of odor

\begin{tabular}{|c|c|c|c|c|c|}
\hline \multirow{2}{*}{ Point No. } & \multirow{2}{*}{$\begin{array}{l}\text { Distance from the } \\
\text { landfill boundary, } \mathrm{m}\end{array}$} & \multicolumn{2}{|c|}{$\begin{array}{l}\text { Degree of non-coverage of the tree trunk with } \\
\text { lichens, \% }\end{array}$} & \multicolumn{2}{|c|}{ Strength of odor, \% } \\
\hline & & absolute & relative & absolute & relative \\
\hline 1 & 500 & 44 & 53.79 & 29.79 & 32.94 \\
\hline 2 & 400 & 64.6 & 78.97 & 43.62 & 48.23 \\
\hline 3 & 300 & 74.8 & 91.44 & 55.32 & 61.23 \\
\hline 4 & 200 & 79.5 & 97.18 & 67.02 & 74.11 \\
\hline 5 & 100 & 80.5 & 98.41 & 77.66 & 85.87 \\
\hline 6 & 0 & 81.8 & 100 & 90.43 & 100 \\
\hline
\end{tabular}

were identified that most accurately describe the change of these indicators from the landfill boundary (Figure 7).

Thus, the change in odor intensity at a distance from the landfill is linear and is described by the dependence:

$$
y=-0.1317 x+99.999
$$

This mathematical dependence is due to the discrete characteristics of the results of measurements for a certain time interval and a small number of factors that influenced the result. In fact, the level of odor depends only on the distance to the landfill. When measuring in other weather conditions (humidity level, precipitation, wind force), the smell from the landfill can spread to another distance, and therefore the coefficients in mathematical dependence will change, but its form will remain linear. The obtained mathematical dependence characterizes the average level of influence of the landfill on the state of atmospheric air, as the measurements were performed from the leeward side and at the most typical wind speed for the area.

The coverage of tree trunks with lichens with the change of distance to the boundary of the landfill changes according to the polynomial mathematical dependence:

$$
y=-7 \mathrm{E}-07 x^{3}+0.0002 x^{2}-0.0302 x+100.01
$$

Bioindication of the state of atmospheric air with the help of lichens allows to characterize the level of its pollution over a long period, due to the long duration of their life. This to some extent determines the form of mathematical dependence obtained, because at the change of wind speed or other weather conditions and at the reduction of the landfill influence area, lichens that grow over long distances may not be suppressed, or experience it to a lesser extent. During such periods, pollutants are localized in a smaller area and their impact on the condition of lichens near the landfill is more pronounced than on windy and clear days. That is,

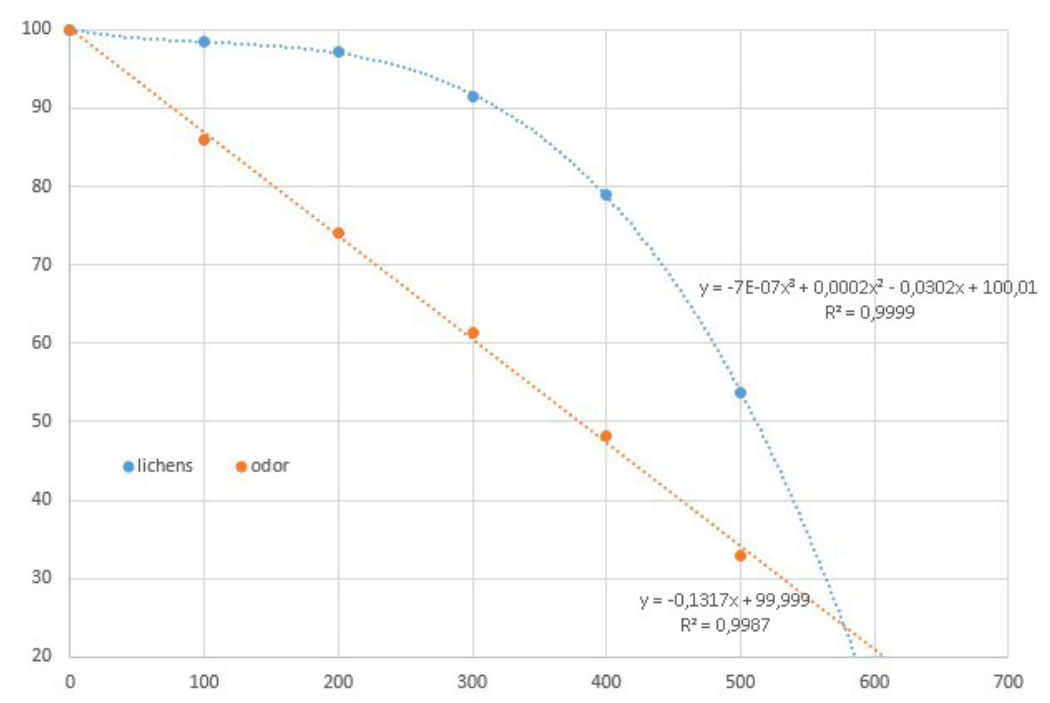

Fig. 7. The results of comparisons ( $\%$ ) of the evaluation of air pollution by the method of coverage of the tree trunk with lichens and the strength of odor 
the response of lichens to air pollution characterizes a certain average value over a long period of exposure. That is why the relative indicators of the degree of non-coverage of tree trunks with lichens when approaching the landfill boundary are slightly higher than the average odor intensity, which characterizes the current air pollution. At the landfill boundary, the influence on the state of atmospheric air is constant and strong. Therefore, its use as a $100 \%$ indicator for both factors studied is acceptable.

The correctness of the obtained mathematical dependences is confirmed by high values of the reliability of the approximation, which is 0.9987 for the intensity of odor and 0.9999 for the degree of non-coverage of tree trunks with lichens. Both of the tested methods can be used in Ukrainian realities to monitor the state of atmospheric air in the area affected by municipal landfills, depending on the purpose of the study.

To determine the area of influence of the landfill, forecast indicators were calculated for both factors studied (Figure 7).

The forecast indicators outline the zone of influence of the Zhytomyr city landfill at a distance of $600 \mathrm{~m}$ from the landfill boundary. However, according to the State Sanitary Rules for Planning and Development of Settlements, the sanitary protection zone around dumps and landfills is only $500 \mathrm{~m}$. This necessitates the revision of standards and the introduction of stricter control over the state of the environment in the area of influence of such objects, which should include not only monitoring of atmospheric air, but also control of surface and groundwater, instrumental analysis of soil, research of species composition and diversity of flora and fauna in the affected area.

The analysis of the results of the conducted research confirmed the significance of the results of the obtained assessment of the influence of the Zhytomyr landfill on the state of atmospheric air.

\section{CONCLUSIONS}

A study was conducted on the intensity of odor from the municipal waste landfill in Zhytomyr (Ukraine) using a human sensory system (ASTM E544 method). It revealed a reliable exponential dependence for modeling the interdependence between the distance from the gas source (the Zhytomyr solid waste landfill) and the odor intensity.
The authors determined the level of atmospheric air pollution on the basis of the assessment of the projective coverage of the trunk with lichens. The analysis of the species composition of lichens and their comparison with the classes of poleotolerance and habitat types of epiphytic lichens confirmed the correctness of this method. Based on the calculations, an exponential dependence was found for modeling the interdependence between the distance from the landfill boundary to the general degree of coverage of the tree trunk with lichens. The results of the study confirmed the correctness of the use of the above method.

An analysis was made of the relationship between the results obtained by the lichen indication method and the strength of the odor from the landfill, for which the results of both studies were interpreted as a percentage and their absolute and relative values were identified. Based on the results of calculation of the relative values of evaluation of atmospheric air pollution by the method of coverage of the tree trunk with lichens and the strength of the odor, a regression analysis was performed and mathematical dependences were identified that most accurately describe the change of these indicators with distance from the landfill boundary.

To determine the influence area of the landfill, forecast indicators were calculated for both studied factors. They outline the influence area of the Zhytomyr city landfill at a distance of $600 \mathrm{~m}$ from the landfill boundary (which is more than the sanitary protection zone $-500 \mathrm{~m}$ ). This necessitates a revision of regulations and the introduction of stricter control over the state of the environment in the area of influence of the object of study.

After conducting 56 studies on odor intensity and 80 evaluations of the general degree of lichen tree trunk coverage, a relationship was found between the strength of the odor from the landfill, the decrease in the degree of lichen tree trunk coverage, and atmospheric air pollution. It is proved that both tested methods can be used in Ukrainian realities to monitor the state of atmospheric air in the area of influence of municipal landfills. The materials of these studies can find further application for the formation of databases of the study of landfills, which will develop a strategy for managing them as an object of increased environmental hazard. 


\section{REFERENCES}

1. ASTM E544-18 Standard Practice for Referencing Suprathreshold Odor Intensity. Retrieved 23 March 2021, from https://www.astm.org/Standards/E544.htm

2. Badtiyev Yu.S. \& Kulemin A.A. 2001. Bioindication is a low-cost and effective method of cognition (in Russian). Ekologicheskiy vestnik Rossiyi, No. $1,38-41$.

3. Byrnes H. \& Frohlich T. 2019. Canada produces the most waste in the world. The US ranks third. Electronic resource USA Today. 24/7 Wall Street, from https:/www.usatoday.com/story/ money/2019/07/12/canada-united-states-worldsbiggestproducers-of-waste/39534923/.

4. Cheng Z., Sun Z., Zhu S., Lou Z., Zhu, N. \& Feng L. 2019. The identification and health risk assessment of odor emissions from waste landfilling and composting. Science of the Total Environment, 649, 1038-1044. doi:10.1016/j.scitotenv.2018.08.230.

5. Compendium of Methods for the Determination of Toxic Organic Compounds in Ambient Air| US EPA. 2021. Retrieved 23 March 2021, from https://www. epa.gov/amtic/compendium-methods-determination-toxic-organic-compounds-ambient-air.

6. Fang J.J., Yang N., Cen D.Y., Shao L.M. \& He P.J. 2012. Odor compounds from different sources of landfill: characterization and source identification. Waste Manag., 32(7), 1401-1410.

7. Getman A.P. \& Lozo V.I. 2017. Harmonization of Ukrainian Waste Treatment Laws with EU Legislation. Environmental Policy and Law / Ekolohichna Polityka i Pravo, 47(1), 48-52.

8. Gorova A., Pavlychenko A., Borysovska O. 2013. The study of ecological state of waste disposal areas of energy and mining companies. Annual ScientificTechnical Colletion - Mining of Mineral Deposits, 2013, 169-171.

9. Kondratyuk, S. 2016. Lichen indication. Retrieved 23 March 2021, from http://esu.com.ua/search_articles.php?id=55887.

10. Korbut M.B. 2015. Ensuring environmental safety of solid waste landfills (in Ukrainian). Ph.D. Thesis, Kremenchuk Mykhailo Ostrohradskyi National University, Kremenchuk.

11. Korbut M.B. \& Malyovanyy M.S. 2013. Prevention of water basin pollution in the area of impact of the Zhytomyr landfill by treatment of wastewater from organic pollutants, ammonium nitrogen and heavy metals. Visnyk ZhDTU, 67(4), 127-134.

12. Krasnogorskaya N.N., Zhuravlyeva S.Ye. \& Minnullina G.R. 2004. Lichenoindication scales for assessing the quality of atmospheric air. Basic Research (in Russian), 5, 38-42.
13. Lee Y.Y., Jung H., Ryu H.W., Oh K.C., Jeon J.M. \& Cho K.S. 2018. Seasonal characteristics of odor and methane mitigation and the bacterial community dynamics in an on-site biocover at a sanitary landfill. Waste Manag, 71, 277-286.

14. Liu Y., Lu W., Li D., Guo H., Caicedo L., Wang C., Xu S. \& Wang H. 2015. Estimation of volatile compounds emission rates from the working face of a large anaerobic landfill in China using a wind tunnel system. Atmos. Environ. 111, 213-221.

15. Malovanyy M., Moroz O., Hnatush S., Maslovska O., Zhuk V., Petrushka I., Nykyforov V. \& Sereda A. 2019. Perspective Technologies of the Treatment of the Wastewaters with High Content of Organic Pollutants and Ammoniacal Nitrogen. Journal of Ecological Engineering, 20(2), 8-15. https://doi. org/10.12911/22998993/94917

16. Manning W.J., \& Feder W.A. 1980. Biomonitoring air pollutants with plants. Biomonitoring Air Pollutants with Plants.

17. Mishchenko V., Makovetska Y. \& Omelyanenko T. 2013. Institutional development of waste management in Ukraine: towards European Integration. Institute of Environmental Economics and Sustainable Development National Academy of Sciences of Ukraine, 192.

18. Omelyanenko T.L. \& Makovetska Yu.M. 2015. Directions for improving environmental policy in the field of waste management in Ukraine based on the relevant experience of the European Union (in Ukrainian). Ekonomika pryrodokorystuvannya i okhorony dovkillya, 35-43.

19. Osypova T.A. \& Remez N.S. 2015. Prediction of biogas yield and landfill temperature of solid waste based on mathematical modeling (in Ukrainian). Visnyk Kremenchuk Mykhailo Ostrohradskyi National University, 3(92), 144-149

20. Pavlychenko A., Kovalenko, A. 2013. The investigation of rock dumps influence to the levels of heavy metals contamination of soil. Annual ScientificTechnical Colletion - Mining of Mineral Deposits, 2013, 237-238.

21. Pecorini I., Baldi F., Bacchi D., Carnevale E.A. \& Corti A. (2017. Leaching behaviour of hazardous waste under the impact of different ambient conditions. Waste Manag., 63, 96-106.

22. Pecorini I., Rossi E. \& Iannelli R. 2020. Mitigation of methane, NMVOCs and odor emissions in active and passive biofiltration systems at municipal solid waste landfills. Sustainability (Switzerland), 12(8) doi:10.3390/SU12083203

23. Popovych N.P. (201. Environmentally safe collection, transportation and disposal of solid waste. (in Ukrainian) Ph.D. Thesis, Lviv State University of Life Safety, Lviv. 
24. Popovych V., Stepova K. \& Prydatko O. 2018. Environmental hazard of Novoyavorivsk municipal landfill. In: MATEC, Web of Conferences 247, 00025. FESE 2018. https://doi.org/10.1051/ matecconf/201824700025

25. Popovych V., Telak J., Telak O., Malovanyy M., Yakovchuk R. \& Popovych N. 2020. Migration of hazardous components of municipal landfill leachates into the environment. Journal of Ecological Engineering, 21(1), 52-62. https://doi. org/10.12911/22998993/113246

26. Radovenchyk V.M. \& Homelya M.D. 2010. Solid waste: collection, processing, storage (in Ukrainian). Kiev, Condor, 552.

27. Rossi E., Frasi N., Pecorini I. \& Ferrara G. 2018. Methane oxidation efficiency and NMVOCs reduction in a full-scale passive bioifltration system for the treatment of residual landfill gas. Procedia Environ. Sci. Eng. Manag., 5, 147-152.

28. Safranov T.A., PrykhodkoV. Yu. \& Shanina T.P. 2016. The problem of waste disposal in landfills and landfills of Odessa region (in Ukrainian). Visnyk KhNu im. V.N Karazina, 14, 83-90

29. Sagdeeva O.A., Krusir H.V. \& Tsykalo A.L. 2018. Assessment of the level of environmental hazard of municipal solid waste landfills (in Ukrainian). Ekolohichna bezpeka, 1, 75-83.

30. Sagdeeva O.A. 2018. Improving the technology of composting the food component of solid waste. Ph.D. Thesis, Odessa National Academy of Food Technologies, Odessa.

31. Skyba T., Popovych V., Dominik A., Rudenko, D., Bosak, P. 2020. Dose rate of the landfills of north-west podillya (Ukraine). International Multidisciplinary Scientific GeoConference Surveying Geology and Mining Ecology Management, SGEM, 259-266. https://doi.org/10.5593/sgem2020/5.1/s20.033

32. Stalinska I.V. 2016. Peculiarities of ecological safety in the system "solid household waste-environment-human health" (in Ukrainian). Naukovyy visnyk NLTU Ukrainy, 26(7), 238-244.

33. State building codes of Ukraine. 2005. Landfills for solid waste. Basic design provisions. (in Ukrainian). DBN B.2.4-2-2005. Kiev.

34. Stolaroff J.K., Bhattacharyya S., Smith C.A., Bourcie, W.L., Cameron-Smith P.J. \& Aines R.D. 2012. Review of methane mitigation technologies with application to rapid release of methane from the arctic. Environ. Sci. Technol., 46, 6455-6469.

35. Trass H. 1973. Lichen sensitivity to the air pollution and index of poleotolerance (I.P.). Folia Cryptogamica Estonica, No. 3.

36. Trass H.H. 1985. Classes of field tolerance of lichens and ecological monitoring. Probl. Eco. Monitoring and Modeling Ecosystems (in Russian). Leningrad. Vol. 7.

37. Tymchuk, I., Malovanyy, M., Shkvirko, O., Zhuk, V., Masikevych, A., Synelnikov, S. 2020. Innovative creation technologies for the growth substrate based on the man-made waste-perspective way for ukraine to ensure biological reclamation of waste dumps and quarries. International Journal of Foresight and Innovation Policy, 14(2-4), 248-263.

38. Vambol S., Vambol V., Bogdanov I., Suchikova,Y. \& Rashkevich N. 2017. Research of the influence of decomposition of wastes of polymers with nano inclusions on the atmosphere. Eastern-European Journal of Enterprise Technologies, 6(10-90), 57-64. https://doi.org/10.15587/1729-4061.2017.118213

39. Waste Atlas, 2013 Report. Website: http://www.dwaste.com.

40. Waste Atlas The World's 50 Biggest Dumpsites. (2014). Website: http://www.d-waste.com.

41. Wu C., Liu J., Liu S., Li W., Yan L., Shu M., Zhao P., Zhou P. \& Cao W. 2018. Assessment of the health risks and odor concentration of volatile compounds from a municipal solid waste landfill in China. Chemosphere, 202, 1-8. 